\title{
Political Participation Among Federal Employees: The Hatch Act and Political Equality
}

\author{
DAVID R. MORGAN \\ University of Oklahoma \\ JAMES L. REGENS \\ Northern Arizona University
}

Is the federal career employee a second class citizen politically? Some seem to think so (Cayer, 1975: 117), especially in light of the recent U. S. Supreme Court decision reaffirming the basic premises of the 1939 Hatch Act. This is not really a new question, of course, only one recently revived as an outgrowth of the political activism so prevalent in the 1960s when ever the bureaucrat began to stir as various heretofore silent groups demanded greater access to the political arena. Because of lower court decisions that seem to loosen the bureaucrats' restrictive political barriers (see Martin, 1973), some felt the time had come for a considerable revision of the Hatch Act (Jones, 1969; Martin, 1973). Undoubtedly, this legislation has been successful in barring federal employees from engaging in certain overt political activities that presumably would jeopardize the ancient goal of the neutral but competent career service. But, to date, little is really known about the bureacrat's political attitudes or behavior that might be used to assess empirically the degree to which his activities are indeed circumscribed.

Most Americans are notoriously ignorant of politics and remain largely uninvolved in political and civic affairs. Are bureaucrats any different? If the most intensive activities are excluded, do they participate politically about the same as other citizens? Do the same factors contribute to greater levels of participation among federal bureaucrats as are found among the population at large? Given the longstanding interest in the Hatch Act and its impact, we have surprisingly little information concerning the political attitudes and behavior of federal civil servants. The research that follows will attempt to provide some additional insights into issues such as these.

David R. Morgan is associate professor of political science at the University of Oklahoma where he teaches urban and state politics, urban administration, and policy analysis. His work has appeared in a number of professional journals, and he is the co-editor (with Samuel A. Kirkpatrick) of Urban Political Analysis (Free Press, 1972).

James L. Regens received the Ph. D. from the University of Oklahoma and currently serves as assistant professor of political science at Northern Arizona University, Flagstaff, where he teaches urban and state politics, policy analysis, political methods, and political behavior. He has authored several monographs and articles in his fields of interest.

193 


\section{Political Participation and the Federal Bureaucrat}

We begin with the assumption that, excluding the most intensive partisan acts, bureaucrats are likely to be about as politically active as most Americans. Whether this relative low level of involvement, if it exists, results from Hatch Act constraints or is due more to general indifference may be difficult to determıne, although responses to certain questions to be analyzed below may help shed light on this matter.

Much of the abundant literature on political activity generally was summarized in the mid-sixties by Milbrath in Political Participation 11965). Among the conceptual problems considered in this volume, the author posits a hierarchy of political involvement with three basic levels - spectator activities, transitional activities, and gladiatorial activities. This hierarchical concept of participation has been challenged recently in Verba and Nie's definitive work, Participation in America (1972), in which they argue that participation should be considered as a multidimensional phenomenon. Citizens tend to concentrate their efforts in small clusters of related activities that do not form a neat pyramid according to the findings of these authors. While this more sophisticated approach yields impressive results for a cross-sectional analysis of $U$. S. citizens, the authors were forced to rely on a single additive measure of participation Iderived from Survey Research Center results) when they wanted to put their findings into longitudinal perspective. The results of this time series analysis were quite consistent with the findings from the more conceptually elaborate cross-sectional model (Verba and Nie, 1972: Chapter 14). Because of data limitations, the analysis to follow will also rely upon a single measure of participation, but given the comparability of the Verba and Nie findings, we believe the results can be considered useful and valid.

Although this is not the place for an exhaustive treatment of the many social, economic, political, and personal factors associated with variation in levels of political participation, we must be guided by some theoretical framework in our effort to understand the behavior of federal bureaucrats. Basically most studies have attempted to assess the extent to which such things as socioeconomic status, life cycle, sex, and race, along with certain political attitudes, contribute to greater political involvement. To the extent any theory exists it seems to be a derivation of the basic theme that various background characteristics are subsequently affected by environmental conditions and various perceptual processes, all of which ultimately shape the individual's political behavior (Milbrath, 1965: pp. 28-38). Verba and Nie (1972), for example, employ an approach to explain their four basic modes of activity which assumes that socioeconomic 
status (SES) and civic orientations contribute to the level of activity in a causal fashion with SES related directly to both civic orientations and political activity. ${ }^{1}$ Since one of our primary objectives is to compare federal employee attitudes and behavior with national norms, we will also use a derivation of this basic model to explain variations among federal employees.

\section{Comparing Federal Employees with the General Public}

The information concerning political attitudes and behavior of federal bureaucrats was collected by the Survey Research Center in 1967 as a part of a report to the Federal Commission on the Political Activity of Government Personnel. Personal interviews were conducted with a sample of 980 full-time federal civilian employees age 21 or over who had been in federal service at least one year and were employed in the continental U. S. ${ }^{2}$

As an initial step in exploring the political behavior of federal employees, Table 1 presents some basic percentage comparisons between that group, a Survey Research Center national sample for $1968,{ }^{3}$ and certain comparable national data from the Verba and Nie study gathered in 1967. The results of Table 1 clearly confirm that, for most political activities, federal employees do as well and frequently better than the national population (also see Halter, 1972). The principal exception, as expected, concerns those acts that would likely bring the employee into conflict with Hatch Act provisions (especially the last item shown - working for a party or candidatel. We might note that the questions used in the three studies were not always worded exactly the same, and for the federal employee study, the question asked if the particular act had occurred at any time since 1960. Of those who had performed such ac-

1The four modes of participation "voting, campaign activity, communal activity. and particularized contact" are derived through factor analysis using $r$ in the factor matrix (Verba and Nie, 1972: 135). Beck 11974) argues that only two factors of political participation result when phi phi max instead of $r$ is used in the correlation matrix.

2The results of the study can be found in the Commission on Political Activity of Government Personnel (1967). The sample frame included about 167,000 employees. Excluded were employees of the FBI, CIA, AEC, legislative and judicial branches. along with a few very small agencies. These data are made available on tape from the Survey Research Center, Inter-University Consortium for Political Research, University of Michigan, Ann Arbor.

3These data are taken from the marginals in Survey Research Center (1973). 
tivities, $87 \%$ indicated that these things were done either after 1960 or both before and after. Thus, while it is possible that some responses for the bureaucrats might be slightly inflated, it still would seem that, in general, federal employees are slightly more politically active than other citizens.

Turning to an examination of those factors associated with varying levels of participation, we hypothesize that background and attitudinal characteristics should be the principal forces motivating federal bureaucrats to get involved politically. These measures and their characteristics are found in Table 2. Since much of the information used by Verba and Nie (1972) was not included as part of the federal employee study, in constructing our dependent variable we have used the same approach as did those authors when comparing their findings longitudinally, i. e., construction of a single composite index of participation comprised of the last items listed in Table 1. The only other items requiring further explana. tion are the two attitudinal indices that were constructed as described below and the one question pertaining to the Hatch Act. This latter item, which asks whether or not the respondent would be more active "if Federal Workers were allowed to do more things in politics . . .?", was dichotomized into a "more" and "same" response. "The efficacy index is made up of four items developed by the SRC in the 1950s and subsequently used in a number of voting studies, ${ }^{5}$ while the competence measure consists of four questions regarding how likely it is that the respondents would try to change or succeed in changing both a local law and federal law. ${ }^{6}$

4This dichotomous measure was collapsed by combining responses of "lot more active" and "somewhat more active" into a "more active" category leaving "little-bit more active" and "stay about the same" in a "stay the same" category. Twenty-two per cent are in the "more active" group.

5The political efficacy measure consists of the following items (paraphrased):

(1) Not much to say about the Government.

(2) Voting only way to control Government.

(3) Government too complicated.

(4) Officials don't care about me.

For a discussion of the limitations of this measure see Balch (1974) and Asher (1974). phrased):

6The political competence measure consists of the following questions (para-

(1) If you made an effort to change this (unjust or harmful local) regulation, how likely is it that you would succeed?

(2) If such a case arose, how likely is it that you would actually try to do something about (it)?

(3) Same as question 1 with unjust or harmful federal law included.

(4) Same as question 2. 
TABLE 1

COMPARISON OF VARIOUS POLITICAL ACTIVITIES AMONG TWO NATIONAL SAMPLES AND FEDERAL EMPLOYEES

\begin{tabular}{lccc}
\hline \multicolumn{1}{c}{ Activity } & $\begin{array}{c}\text { National } \\
\text { SRC } \\
(\mathrm{N}=1336)\end{array}$ & $\begin{array}{c}\text { National } \\
\text { Verba \& Nie } \\
(\mathrm{N}=2549)\end{array}$ & $\begin{array}{c}\text { Federal } \\
(\mathrm{N}=980)\end{array}$ \\
\hline Vote for President, 1964 & $70.7 \%$ & $70.2 \%$ & $85.3 \%$ \\
Try to Influence Vote of Others $\dagger$ & 32.9 & 40.1 & 41.0 \\
Given Money to Party or Candidate (Last Year) & 8.8 & 13.1 & 7.2 \\
Worn Campaign Button or Sticker on Car $\dagger$ & 14.8 & $\mathrm{NA}$ & 18.2 \\
Attend Political Meetings or Rallies ${ }^{\dagger}$ & 9.1 & 19.2 & 22.2 \\
Ever Belong to Political Organization ${ }^{\dagger}$ & 3.4 & $\mathrm{NA}$ & 3.0 \\
Ever Work for Party or Candidate $\dagger$ & 5.8 & $13.6+$ & 4.2 \\
\hline
\end{tabular}

$\dagger$ This question for the federal sample asked if any of these acts had occurred since 1960. However, in response to a question concerning whether or not these ac. tivities took place before or after the respondent became a federal employee, 86.6\% who indicated they had done these things replied either "after" or "both."

\$xcludes responses of "a few elections" and "never."

TABLE 2

\section{CHARACTERISTICS OF VARIABLES USED IN MULTIVARIATE ANALYSIS}

\begin{tabular}{|c|c|c|c|}
\hline & $\bar{X}$ & S. D. & Range \\
\hline $\begin{array}{l}\text { Background Characteristics } \\
\mathrm{X}_{1} \text { SES Index } \dagger\end{array}$ & 3.71 & 1.69 & 1.7 low=high SES) \\
\hline $\mathrm{X}_{2}$ Race & .84 & .37 & $0-1(0=$ black $)$ \\
\hline $\mathrm{X}_{3}$ Age & 3.15 & 1.04 & $1-5$ (9 year intervals) \\
\hline$X_{4}$ Sex & .76 & .43 & $0-1(0=$ female $)$ \\
\hline$X_{5}$ Length-Federal Service & 2.10 & .84 & 1.4 (9 year intervals) \\
\hline $\begin{array}{l}\text { Attitudinal Measures } \\
\mathrm{X}_{6} \text { Efficacy Index }\end{array}$ & 3.58 & 1.18 & $1-5$ (low =high efficacy) \\
\hline $\mathrm{X}_{7}$ Competence Index & 2.80 & 1.37 & 1-5 $($ low $=$ high competence $)$ \\
\hline $\mathrm{X}_{8}$ Strength of Union Activity & 1.81 & 1.09 & $1.4($ low $=$ inactive $)$ \\
\hline $\mathbf{X}_{9}$ Strength of Party ID & 2.66 & 1.08 & $1.4 \quad($ low $=$ strong $)$ \\
\hline $\mathrm{X}_{10}$ Greater Activity If Permitted & .40 & .49 & $0.1 \quad($ same $/$ more $)$ \\
\hline $\begin{array}{l}\text { Dependent Variable } \\
\text { Y }_{1} \text { Political Participation } \\
\text { Index }\end{array}$ & 5.94 & 1.22 & $1-7($ low $=$ high participation $)$ \\
\hline
\end{tabular}

Combines four point scale for both education and income. 
Initially these five background and five attitudinal measures were used in a multiple regression equation to explain participation levels with the following results using standardized partial regression coefficients:

$$
\begin{aligned}
& Y_{1}=6.59-.10 \mathrm{X}_{1}-.02 \mathrm{X}_{2}+.05 \mathrm{X}_{3}-.04 \mathrm{X}_{4}+.05 \mathrm{X}_{5}-.10 \mathrm{X}_{6} \\
& +.18 \mathrm{X}_{7}-.04 \mathrm{X}_{8}-.12 \mathrm{X}_{9}-.21 \mathrm{X}_{10} \quad 1 \mathrm{R}^{2}=.1631
\end{aligned}
$$

The level of explained variance is modest at best and yet compares favorably with those reported by Verba and Nie 11972: p. 135) for the total population. ${ }^{7}$ On the basis of the $t$-ratio, five of the independent variables are significant at the .01 level: SES Index, Efficacy. Competence, Strength of Party ID. and "Greater Activity if Permitted." Since four of these are attitudinal measures, it raises a question concerning the degree to which one of Verba and Nie's basic findings, that SES characteristics are more dominant in explaining political participation than are attitudinal measures. applies to federal bureaucrats.

As a further test of the relative impact of background characteristics and attitudinal measures in accounting for participation levels among bureaucrats. multiple-partial coefficients were calculated. This exercise confirms the prime importance of attitudes as opposed to background as indicated by the following coefficients:

$$
\begin{array}{ll}
\text { Attitudes (controlling for background) } & \mathrm{r}^{2} 2.1=.146 \\
\text { Background (controlling for attitude) } & \mathrm{r}^{2} 1.2=.034
\end{array}
$$

Why attitudinal variables should be more salient for federal employees than the larger public is not altogether clear. In some respects federal bureaucrats represent a fairly broad cross-section of the country, and yet in one important way they differ rather significantly. Census estimates for 1968 reveal that only $20.1 \%$ of the U. S. had completed more than 12 grades of education; among the federal sample this percentage was 36.4 . Perhaps the political behavior of those with higher levels of education is less rigidly determined by background characteristics and more immediately affected by attitudinal ordering and the operation of certain perceptual devices. In fact, this assumption fits a good bit of the general literature on the impact of education on political involvement (Milbrath, 1965: pp. 53-54).

7The following $\mathrm{R}^{2}$ 's are reported for the four modes of participation listed in footnote 1 above $-.152, .194, .230, .014-$ using only SES plus civic orientations. Verba and Nie (1972; Appendix G) provide a well-reasoned argument for the use of parametric linear statistics with ordinal data. For a more statistically-oriented discussion see Labovitz (1970). 
We should also note the particular importance of the question relating to changing the Hatch Act. Strictly speaking, the effect of this variable doesn't prove that greater activity would result if the Hatch Act were so modified. It does reveal that those who would do more if they were permitted are currently more active than their fellow employees. In one sense, this might be taken as an indication that for some federal employees, at least, easing of Hatch Act constraints might well produce more political participation. While this might be the result for some, it appears certain that only a small minority would increase their level of political activity in any significant way if the Hatch Act permitted (also see Bernick and Rinehart, 1974).

\section{Conclusion}

On the face of it, the Hatch Act appears to impose rather severe limits on the political activity of federal employees, and partly because of this, sentiment has been growing for its repeal or modification. Although there may be other grounds on which to urge this action, the research reported here suggests that such changes would make very little difference in the political behavior of most federal bureaucrats who currently participate at only slightly higher rates than other U. S. citizens. It also seems that the same socioeconomic and attitudinal measures can account for about the same degree of participation among this group as among the larger population. One important distinction does appear, however. Apparently attitudinal variables are more powerful than measures of socioeconomic status in determining participation levels for federal employees, a finding contrary to that for the population as a whole.

\section{REFERENCES}

Asher, H. B., "The Reliability of the Political Efficacy Items," 1 Political Methodology (Spring, 1974), pp. 45-72.

Balch, G. I., "Multiple Indicators in Survey Research: The Concept of Political Efficacy," I Political Methodology (Spring, 1974), pp. 1-43.

Beck, N., "A Note on Factoring Participation Variables," 1 Political Methodology (Fall, 1974), pp. 97-102.

Bernick, E. L. and J. Rinehart, "Political Attitudes and Behavior Patterns of Federal Civil Servants," 35 Public Administration Review (November/December, 1975), pp. 603-611.

Cayer, N. J., Public Personnel Administration in the United States (New York: St. Martin's Press, 1975).

Commission on Political Activity of Government Personnel, "A Commission Report: Research, Vol. 2" (Washington, D. C.: Government Printing Office, 1967).

Halter, G., "The Effects of the Hatch Act on the Political Participation of Federal Employees," 16 Midwest Journal of Political Science (December, 1972), pp. 723.729 
Junes, C. O., "Reevaluating the Hatch Act: A Report on the Commission on Political Activity of Government Personnel," 29 Public Administration Review (May June, 1969), pp. 249-254.

Labovitz, S.. "The Assignment of Numbers to Rank Order Categories," 35 American Sociological Reviex (June, 1970), pp. 515-525.

Martin, P. L., "The Hatch Act in Court: Some Recent Developments," 33 Public Administration Review (September/October, 1973), pp. 443-447.

Milbrath, L. W., Political Participation: How and Why Do People Get Involved in Politics? 'Chicago: Rand McNally, 1965).

Survey Research Center, "1968 American National Election Study" (Ann Arbor, Michigan: Inter-University Consortium for Political Research, 1973).

Verba, S. and N. H. Nie, "Participation in America: Political Democracy and Social Equality" (New York: Harper \& Row, 1972).

\title{
BOOK NOTES
}

\author{
WILL APPEAR IN
}

MARCH AND SEPTEMBER ISSUES 